\title{
Insiden dan Gambaran Klinis Hepatitis Akibat Obat Anti Tuberkulosis di Rumah Sakit Umum Daerah Dr. Saiful Anwar Malang
}

\author{
Incidence and Clinical Features of Anti-tuberculosis Drug Induced Liver Injury (ATLI) in Saiful \\ Anwar Hospital Malang
}

\author{
Achmad Rifa'i, Budi Herlianto, Syifa Mustika, Bogi Pratomo, Supriono \\ Laboratorium Ilmu Penyakit Dalam Rumah Sakit Umum Daerah Dr. Saiful Anwar Malang
}

\begin{abstract}
ABSTRAK
Hepatitis akibat obat anti tuberkulosis (OAT) merupakan ancaman yang serius terhadap pengendalian penyakit tuberkulosis. Namun belum ada data yang representatif mengenai hal tersebut dalam suatu populasi. Penelitian ini bertujuan untuk memahami gambaran klinis dan mengevaluasi efek dari terapi obat anti tuberkulosis di Rumah Sakit Umum Daerah Dr. Saiful Anwar Malang pada tahun 2013. Penelitian ini merupakan penelitian deskriptif potong-lintang (cross sectional) yang melibatkan sebanyak 460 pasien tuberkulosis (TB) yang menerima directly observed treatment strategy (DOTS). Dari hasil penelitian diperoleh 25 pasien yang mengalami hepatitis akibat OAT dengan nilai insiden sebesar 5,4\%. Gejala-gejala yang paling sering timbul adalah rasa mual dan muntah (48\%). Terjadi hepatitis ringan (20\%), sedang (48\%), berat (4\%), dan sengat berat (4\%). Sebanyak $60 \%$ tanpa penyakit penyerta. Efek Hepatitis yang menyebabkan pemberhentian OAT sementara sebesar $56 \%$ kasus dan yang tetap meneruskan OAT sebesar $44 \%$ kasus, rata-rata durasi terapi hepatitis akibat Obat Anti Tuberkulosis adalah 18 hari. Hepatitis akibat OAT dapat mempengaruhi angka keberhasilan (outcome) terapi. Adanya insiden hepatitis akibat OAT dan besarnya populasi Hepatitis tersebut di Rumah Sakit Saiful Anwar menunjukkan bahwa mendeteksi efek negatif dari terapi OAT sangatlah penting.
\end{abstract}

Kata Kunci: Anti-tuberculosis drug induced liver injury (ATLI), Obat Anti Tuberkulosis (OAT), tuberkulosis paru

\begin{abstract}
Anti-tuberculosis drug induced liver injury (ATLI) emerges as a significant threat to tuberculosis control, though there is no representative data available about the conditionon a certain population. This study is aimed to better understand its clinical features and to evaluate its impact of anti-tuberculosis (TB) treatment in Saiful Anwar Hospital in 2013. This research is a cross-sectional descriptive study involving as many as 460 TB patients receiving directly observed treatment strategy (DOTS).The results show 25 patients developed ATLI equal to incidence rate of 5,4\%. The most arising symptoms are nause and vomiting (48\%). There were also mild (20\%), moderate (48\%), severe (4\%), and very severe hepatotoxicity (4\%). As many as $60 \%$ was without concomitant disease. Impact of ATLI which caused temporal dismissal of treatmentwas $56 \%$ of cases and continuing OAT was $44 \%$ ofcases, theaverage duration of ATLI treatment was 18 days. ATLI could considerably impact the outcomes of anti-TB treatment. The incidence of ATLland the size of TB population in Saiful Anwar Hospital, detecting negative impact of anti-TB treatment is substantial.
\end{abstract}

Keywords: Anti-tuberculosis drug induced liver injury (ATLI), lung tuberculosis, anti-tuberculosis drug (ATD)

Jurnal Kedokteran Brawijaya, Vol. 28, No. 3, Februari 2015; Korespondensi: Achmad Rifa'i. Laboratorium Imu Penyakit Dalam Rumah Sakit Umum Daerah Saiful Anwar Malang, Jl. Jaksa Agung Suprapto No. 2 Malang Tel. (0341) 362101 Email: rifaiachmad4@gmail.com ataudwirifai76@yahoo.co.id 


\section{PENDAHULUAN}

Tuberkulosis (TB) masih menjadi permasalahan kesehatan utama dengan angka insiden 9,4 juta kasus dan 1,7 juta mortalitas secara global di tahun 2009 (1). Lima negara endemik TB adalah India, China, Afrika Selatan, Nigeria, dan Indonesia. Pengendalian TB dilakukan dengan strategi Directly Observed Treatments, Short-course (DOTS). Komponen utama strategi DOTS adalah regimen kemoterapi anti-TB standar jangka pendek yang mengharuskan secara kontinu untuk mengkonsumsi obat kombinasi seperti Isoniazid (H), Rifampicin (R), Pyrazinamide (Z), Ethambutol (E), dan Streptomycin (S) setiap hari selama 6-9 bulan.

Meskipun obat anti TB (OAT) memiliki kemampuan bakteriosidik dan bakteriostatik terhadap Mycobacterium tuberculosis, namun OAT juga menginduksi berbagai efek samping, termasuk hepatotoksis, reaksi kulit, gangguan gastrointestinal dan gangguan neurologis $(2,3)$. Antituberculosis drug induced liver injury (ATLI) merupakan salah satu efek samping utama yang penting dan serius $(4,5)$ yang hampir mencapai angka $7 \%$ dibandingkan efek samping yang lain $(6,7)$. Insiden $A T L I$ dilaporkan bervariasi dari $2 \%$ hingga $28 \%$ berdasarkan populasi yang berbeda (4). Selain itu, ATLI dapat menurunkan efektivitas terapi TB, menyebabkan penurunan kepatuhan minum obat, dan akan mengarah pada kegagalan terapi, timbulnya kekambuhan, dan timbulnya resistensi obat $(4,8,9)$. Keseluruhan dampak negatif tersebut secara signifikan akan mengganggu pengendali epidemi kasus TB. Pada beberapa pasien di Rumah Sakit dr. Saiful Anwar (RSSA) Malang dengan kondisi ATLI yang severe, pengobatan OAT harus di hentikan sampai kondisi ATLI membaik. Penghentian OAT ini sangat bervariasi antar individu. Akibat penghentian OAT kemungkinan pasien berisiko mengalami perburukan penyakit TB atau risiko resistensi menjadi lebih tinggi.

Data epidemiologi yang menggambarkan insiden terjadinya ATLI sangat dibutuhkan. Disamping itu diperlukan juga upaya mengidentifikasi efek samping lebih dini dan melakukan intervensi tepat waktu dalam mengahadapi kasus ATLI. Memahami gambaran klinis dari ATLI seperti waktu onset, keparahan, gejala klinis utama, dan outcome terapi merupakan hal yang sangat penting. Tujuan dari penelitian ini adalah untuk mengkaji gambaran klinis dan angka kejadian ATLI di RSSA pada tahun 2013.

\section{METODE}

Penelitian dilakukan secara deskriptif dengan desain cross sectional. Data diambil dari rekam medis baik pasien rawat jalan maupun rawat inap yang menjalani terapi OAT di RSSA Malang pada bulan Januari 2013-Desember 2013, mengalami hepatitis yang disebabkan bukan karena infeksi akut virus Hepatitis, hepatitis imbas obat non- OAT.

Kriteria ATLI antara lain peningkatan serum alanine transaminase $(A L T)$ atau aspartate transaminase (AST) lebih dari 3 kali nilai atas normal (ULN) atau nilai TBil lebih dari 2 kali nilai normal ULN. Berdasarkan definisi tersebut keparahan hepatitis ditentukan sebagai berikut: mild ( $3 x$ $\mathrm{ULN}<$ ALT atau AST $\leq 5 \times$ ULN, atau $2 \times \mathrm{ULN}<\mathrm{TBil} \leq 5 \times \mathrm{ULN}$ ) dan severe (ALT atau AST atau TBil $>5 \times$ ULN). Secara statistik, karakteristik pasien digambarkan dalam nilai ratarata (mean) dan persentase.

\section{HASIL}

\section{Karakteristik Pasien}

Pada penelitian ini didapatkan 460 pasien TB menerima terapi directly observed treatment strategy (DOTS) dan 25 pasien (insiden 5,4\%) mengalami ATLI. Rerata usia pasien TB adalah 40,60 $\pm 18,267$ dengan $60 \%$ berusia antara $25-50$ tahun. Pasien perempuan lebih banyak dibandingkan dengan pasien laki-laki yakni sebanyak 15 orang (60\%). Penyakit primer terbanyak dari paru (92\%) dengan jenis terapi TB kategori 1 yang terbanyak yakni sebesar $84 \%$. Lama OAT< 1 bulan sebesar $52 \%$ dengan tanpa penyakit penyerta sebesar $60 \%$ (Tabel 1 ).

Tabel 1. Karakteristik pasien TB yang mengalami ATLI

\begin{tabular}{llr}
\hline \multicolumn{1}{c}{ Kategori } & Sub Kategori & \multicolumn{1}{c}{ Hasil } \\
\hline Umur (mean \pm SD) & & $40,60 \pm 18,267$ \\
& $<25$ tahun & $3(12 \%)$ \\
& $25-50$ tahun & $15(60 \%)$ \\
Jenis kelamin & $>50$ tahun & $7(28 \%)$ \\
& Laki-laki & $10(40 \%)$ \\
Diagnosis & Perempuan & $15(60 \%)$ \\
& TB paru & $23(92 \%)$ \\
Jenis terapi & TB ekstra paru & $2(8 \%)$ \\
& TB kategori 1 & $21(84 \%)$ \\
Lama OAT & TB kategori 2 & $4(16 \%)$ \\
& $<1$ bulan & $13(52 \%)$ \\
Penyakit penyerta & $1-2$ bulan & $9(36 \%)$ \\
& $3-6$ bulan & $3(12 \%)$ \\
& Tanpa penyakit & $15(60 \%)$ \\
& penyerta & $2(8 \%)$ \\
& Hepatitis B & $2(8 \%)$ \\
& HIV & $3(12 \%)$ \\
& Diabetes & $1(4 \%)$ \\
& mellitus & $2(8 \%)$ \\
\hline
\end{tabular}

Keterangan: OAT=Obat Anti Tuberculosis, HIV=Human

immunodeficiency Virus, TB=Tuberculosis

\section{Gambaran Klinis ATLI}

Peningkatan ALT/AST dan TBil setelah terapi terjadi pada 4 pasien dengan peningkatan $>10$ kali ULN. Sebanyak 4 pasien mengalami peningkatan $>5$ kali ULN, 12 pasien dengan peningkatan 3-5 kali ULN, serta 5 pasien dengan $<3$ kali ULN (Tabel 2). Hal ini menunjukkan bahwa sebagian besar pasien mengalami moderate ATLI.

Tabel 2. Peningkatan ALT/AST dan TBil setelah terapi OAT sesuai derajat $A T L I$

\begin{tabular}{clr}
\hline Derajat ATLI & \multicolumn{1}{c}{ Sub Kategori } & \multicolumn{1}{c}{ Hasil } \\
\hline 1 & Mild(OT/PT<3 kali ULN) & $5(20 \%)$ \\
2 & Moderate (3XULN<OT/PT<5 kali ULN) & $12(48 \%)$ \\
3 & Severe(OT/PT>5 kali ULN) & $4(16 \%)$ \\
4 & Very severe (OT/PT>10 kali ULN) & $4(16 \%)$ \\
\hline
\end{tabular}

Keterangan: ALT=Alanin Aminotransferase, AST $=$ Aspartate Aminotranferase, OT=Oxalacetic transaminase, $\mathrm{PT}=$ Pyruvic Transaminase, ULN=Upper limit Normal, TBil-Total Bilirubin 


\section{Keluhan Klinis yang Dialami Pasien}

Pada 25 pasien yang mengalami ATLI, nausea dan vomiting merupakan gejala yang paling sering dialami yakni sebesar $48 \%$ (Tabel 3). Gejala lemah dan jaundice terjadi masing-masing sebesar $8 \%$, sedangkan yang mengalami rash sebesar $4 \%$ serta tanpa keluhan $32 \%$.

Tabel 3. Distribusi frekuensi gejala ATLI

\begin{tabular}{lc}
\hline \multicolumn{1}{c}{ Simptom } & Frekuensi ( \%) \\
\hline Nausea vomiting & $12(48 \%)$ \\
Lemah & $2(8 \%)$ \\
Jaundice & $2(8 \%)$ \\
Rash & $1(4 \%)$ \\
Tanpa keluhan & $8(32 \%)$ \\
\hline
\end{tabular}

Data menunjukkan sebanyak 14 pasien (56\%) tidak melanjutkan OAT, sedangkan 11 pasien (44\%) tetap melanjutkan OAT. Lama terapi $A T L I<15$ hari sebanyak $64 \%$, 15-30 hari sebanyak $28 \%$, dan $>30$ hari sebanyak $8 \%$. Penghentian OAT lebih banyak ditemukan pada kasus dengan ATLI derajat tinggi. Semua pasien yang dilanjutkan terapinya mempunyai ATLI derajat 1 . Data juga menunjukkan tidak ada hubungan antara lama terapi dengan terjadinya ATLI

\section{DISKUSI}

Berdasarkan kriteria diagnosis ATLI didapatkan insiden 5,4\% pada populasi penderita TB di RSSA Malang yang mendapatkan standart pengobatan DOTS anti Tuberkulosa. Angka ini bila dibandingkan secara umum dengan beberapa negara lain tentunya cukup besar, misalnya di negara China insiden berkisar 2,25\% (10), Singapura 5,3\% (11), Hongkong 5\% (12), Kanada 3\% (3), dan Taiwan (16\%) (13). Perbedaan angka insiden ini tentunya juga dipengaruhi pola penelitian pada masingmasing negara. Di China, pola penelitiannya berdasarkan population based, sedangkan negara negara lain termasuk yang di Malang ini berdasarkan hospital based. Pada studi yang dilakukan di rumah sakit tentunya kategori pasien sudah sangatlah komplek, dan tingkat keparahan penyakit yang tinggi sehingga memerlukan monitoring yang lebih ketat $(3,12,13)$.

\section{DAFTAR PUSTAKA}

1. World Health Organization. Global Tuberculosis Control: WHO Report 2010. Geneva: WHO Press; 2010; p. 5.

2. Burman WJ and Reves RR. Hepatotoxicity from Rifampin Plus Pyrazinamide: Lessons for Policymakers and Messages for Care Providers. American Journal of Respiratory and Critical Care Medicine. 2001; 164(7): 1112-1113.

3. Yee D, Valiquette C, Pelletier M, Parisien I, Rocher I, and Menzies D. Incidence of Serious Side Effects from First-Line Antituberculosis Drugs among Patients Treated for Active Tuberculosis. American Journal of Respiratory and Critical Care Medicine. 2003; 167(11): 1472-1477.

4. Tostmann A, Boeree MJ, Aarnoutse RE, de Lange WC,
Adanya ATLI ini tentunya dipengaruhi oleh beberapa faktor, antara lain faktor usia, nutrisi serta adanya penyakit penyerta pada penderita seperti hepatitis B, C maupun HIV. Pada penelitian ini, didapatkan data bahwa rata rata usia pasien 40 tahun, dengan insiden terendah pada usia dibawah 25 tahun yang hanya mencapai 12\%. Pada beberapa literatur disebutkan bahwa keberadaan faktor penyerta memiliki peranan tinggi untuk timbulnya ATLI, seperti adanya hepatitis C pada pasien, maka kemungkinan terjadinya ATLI 4 kali lipat dibanding tanpa hepatits C. Demikian pula pasien dengan HIV yang kemungkinannya sampai 14,4 kali lipat (14). Pada penelitian ini pasien TB yang menderita ATLI, hampir $60 \%$ tanpa penyakit penyerta.

Hampir $88 \%$ pasien pada studi ini mengalami $A T L I$ pada 2 bulan pertama terapi atau initial phase dengan proporsi terbesar (52\%) terjadi pada bulan pertama. Kondisi ini mirip dengan yang terjadi pada beberapa negara misalnya di Iran dengan median onset 14 hari (15), Turki 15 hari (16), sedangkan di Singapura 28 hari (11). Kondisi ini memberikan nilai yang penting terhadap tindakan monitoring pada penderita yang mendapatkan pengobatan OAT. Monitoring efek samping obat harus lebih intensif pada awal terapi.

Studi ini menunjukkan bahwa keluhan pasien yang sering muncul adalah nausea dan vomiting, walaupun keluhan ini tidak spesifik menunjukkan gejala $A T L I$, sehingga adanya keluhan ini pada pasien TB dalam terapi OAT harus mendapatkan perhatian. Diagnosis hepatotoksis akibat OAT didasarkan pada temuan klinis dan temuan laboratoris yang menunujukkan adanya gangguan fungsi liver $(16,17)$.

Pada studi ini didapatkan kondisi pasien dalam kondisi moderate 48\%, dan kondisi berat 32\%. Dengan kondisi ini maka akan berdampak pada lama terapi serta kepatuhan dari pasien (4). Hal ini dikarenakan kemungkinan pada kondisi moderate sampai severe, terapi OAT dapat dihentikan (56\%), dengan tujuan memperbaiki kondisi liver pasien. Pada pasien TB dengan terapi OAT, angka kejadian ATLI 5,4\%. Risiko ini sering terjadi pada tahap awal terapi ( 2 bulan pertama). Diagnosis terhadap kondisi ini harus didasarkan temuan klinis dan laboratoris, hal ini dikarenakan keluhan pasien yang tidak spesifik (nausea \& vomiting). Adanya ATLI pada pasien TB akan mengakibatkan perpanjangan fase pengobatan serta kemungkinan penurunan kepatuhan pasien dalam terapi.

van der Ven AJ, and Dekhuijzen R. Antituberculosis Drug-Induced Hepatotoxicity: Concise Up-To-Date Review. Journal of Gastroenterology and Hepatology. 2008; 23(2): 192-202.

5. Baghaei P, Tabarsi P, Chitsaz E, et al. Incidence, Clinical, and Epidemiological Risk Factors, and Outcome of Drug-Induced Hepatitis Due to Antituberculous Agents in New Tuberculosis Cases. American Journal of Therapeutics. 2010; 17(1): 17-22.

6. Chitturi S and Farrell G. Drug-Induced Liver Disease. In: Schiff ER, Maddrey WC, and Sorrell MF (Eds). Schiff's Diseases of the Liver 9th edition. Philadelphia: Lippincott, Williams \& Wilkins; 2002; p. 1059-1128.

7. Larrey D. Epidemiology and Individual Susceptibility to Adverse Drug Reactions Affecting the Liver. Seminars in Liver Disease. 2002; 22(2): 145-155. 
8. Kaona FAD, Tuba M, Siziya $\mathrm{S}$, and Sikaona L. An Assessment of Factors Contributing to Treatment Adherence and Knowledge of TB Transmission among Patients on TB Treatment. BioMed Central Public Health; 2004; 4: 68.

9. Wares DF, Singh S, Acharya AK, and Dangi R. Nonadherence Totuberculosis Treatment in the Eastern Tarai of Nepal. The International Journal of Tuberculosis and Lung Disease. 2003; 7(4): 327-335.

10. Shang $\mathrm{P}, \mathrm{Xia} Y$, Liu F, et al. Incidence, Clinical Features and Impact on Anti-Tuberculosis Treatment of AntiTuberculosis Drug Induced Liver Injury (ATLI) in China. PLoS ONE. 2011; 6(7): e21836.

11. Teleman MD, Chee CB, Earnest A, and Wang YT. Hepatotoxicity of Tuberculosis Chemotherapy Under General Programme Conditions in Singapore. The International Journal of Tuberculosis and Lung Disease. 2002; 6(8): 699-705.

12. Chang KC, Leung CC, Yew WW, Lau TY, and Tam CM. Hepatotoxicity of Pyrazinamide: Cohort and CaseControl Analyses. American Journal of Respiratory and Critical Care Medicine. 2008; 177(12): 1391-1396.
13. Huang YS, Chern HD, Su WJ, et al. Cytochrome P450 $2 E 1$ Genotype and the Susceptibility to Antituberculosis Drug-Induced Hepatitis. Hepatology. 2003; 37(4): 924-930.

14. Ungo JR, Jones D, Ashkin D, Hollender ES, Bernstein D, Albanese AP, and Pitchenik AE. Antituberculosis DrugInduced Hepatotoxicity. The Role of Hepatitis C Virus and the Human Immunodeficiency Virus. American Journal of Respiratory and Critical Care Medicine. 1998; 157(6Pt1): 1871-1876.

15. Khalili H, Dashti-Khavidaki S, Rasoolinejad M, Rezaie L, and Etminani M. Anti-Tuberculosis Drugs Related Hepatptoxicity; Incidence, Risk Factors, Pattern of Changes in Liver Enzymes and Outcomes. DARU Journal of Pharmaceutical Sciences. 2009; 17(3): 163-167.

16. Gulbay BE, Gurkan OU, Yildiz OA, et al. Side Effects Due to Primary Antituberculosis Drugs During the Initial Phase of Therapy in 1149 Hospitalized Patients for Tuberculosis. Respiratory Medicine. 2006; 100(10): 1834-1842.

17. Benichou C. Criteria of Drug-Induced Liver Disorders. Report of an International Consensus Meeting. Journal of Hepatology. 1990; 11(2): 272-276. 